\title{
PERSPEKTIF PEMBUDIDAYA IKAN MUJAIR TERHADAP PEMELIHARAAN SISTEM RESIRKULASI RAMAH LINGKUNGAN
}

\author{
Raflen Aril Gerungan"1), Indra Fransiskus Xaverius Rompas²), dan Mecky Christofel Telis Pandelaki ${ }^{3)}$ \\ ${ }^{1}$ Departemen Biologi Fakultas Sains dan Teknologi, Universitas Terbuka, Pondok Cabe Pamulang, Tangerang Selatan; \\ email:raflenaril@ecampus.ut.ac.id \\ ${ }^{2}$ Departemen Budidaya Perairan Fakultas Perikanan, Universitas Sariputra Indonesia Tomohon, Kota Tomohon; \\ email: indrafxr@gmail.com \\ ${ }^{3}$ Departemen Agribisnis Fakultas Pertanian, UniversitasSariputra Indonesia Tomohon, Kota Tomohon; \\ email: pandelaki.mecky@gmail.com
}

\begin{abstract}
Understanding the recirculation system as an environmentally friendly ecosystem-based fish farming method is the main thing that fish cultivators can apply in achieving sustainable fish farming. The objective of this research was to determine the perceptions of the fish cultivator community about the recirculation system. This research uses a quantitative approach with descriptive research methods. There are 21 respondents of which $19.05 \%$ with junior high school education and $80.95 \%$ senior high school. Respondents had more than 10 years as fish farmers. The results showed that the majority of respondents had a good perception of the recirculation system $(57.10 \%)$ and the minority had a poor perception $(42.90 \%)$. Furthermore, the perception of willingness to adopt a recirculation system, the majority of respondents did not have a willingness to adopt, $57.10 \%$ and a minority had a willingness to adopt $42.90 \%$. In this study, it can be concluded that the understanding and knowledge of fish cultivators regarding the benefits and advantages of the recirculation system in fish farming will encourage good perceptions, on the other hand, if fish farmers have minimal understanding and knowledge, the majority of fish cultivators have doubts and a lack of willingness to adopt the recirculation system.
\end{abstract}

Keywords :recirculating, fish farming, perception, eco-friendly

\section{PENDAHULUAN}

Budidaya perikanan merupakan salah satu bidang usaha yang dapat dimanfaatkan sebagai sumber pangan. Irwan (2018) menyatakan bahwa budidaya perairan merupakan kegiatan yang melakukan produksi pada biota perairan atau ikan secara umum dalam wadah atau kondisi yang terkontrol atau dapat dikendalikan. Tetapi yang menjadi tantangan adalah bagaimana para pembudidaya ikan mengembangkan pengelolaan budidaya perikanan yang ramah lingkungan. Mengingat pengelolaan yang bersifat konvensional menghadirkan efek samping yang menyebabkan menurunnya kualitas lingkungan sekitar atau degradasi kualitas lingkungan. Menurut Ardi (2013) budidaya ikan dengan keramba jaring apung (KJA) pengelolaannya merupakan pola intensif, dimana penebaran ikan dengan kepadatan tinggi dan menggunakan pakan komersial dalam proses pembesaran, hal ini berimbas masuknya nutrien berlebih ke badan air. Sisa nutrien yang terlepas secara perlahan akan terakumulasi, sehingga menyebabkan kualitas lingkungan menurun atau mengalami degradasi lingkungan.

Meminimalisir degradasi lingkungan membutuhkan solusi dengan penggunaan atau penerapan tekonologi atau metode alternatif dalam pengelolaan budidaya ikan yang berbasis ramah lingkungan. Sampantamit et al., (2020) dalam penelitiannya menyatakan bahwa sangat dibutuhkan strategi pengelolaan yang efektif untuk meminimalkan dampak lingkungan yang berasal dari kegiatan budidaya perairan, bahkan diperlukan strategi atau metode alternatif untuk memberikan 
kontribusi terhadap bumi yang sehat. Oleh sebab itu pembudidaya ikan harus mampu memahami atau memiliki pengetahuan dasar tentang teknologi dalam budidaya ikan yang memiliki pendekatan pengelolaan perikanan berkelanjutan dan berbasis ekosistem untuk menjaga atau mengembalikan keseimbangan ekosistem yang ada.

Pendekatan pengelolaan perikanan berbasis ekosistem yang sifatnya berkelanjutan akan memberikan acuan kepada pembudidaya ikan untuk bisa melakukan pengelolaan dengan mempertimbangkan keseimbangan antara aspek ekologi, sosial, dan ekonomi. Sehingga ini akan sejalan dengan pengelolaan perikanan berbasis ekosistem berkelanjutan yaitu mendorong produktivitas dengan tetap menjaga kualitas lingkungan yang ada (Ambari, 2017). Lebih lanjut pendekatan pengelolaan perikanan berbasis ekosistem merupakan strategi dalam mengembangkan dan memanajemen serta mengintegrasikan budidaya perairan dan ekosistem sehingga dapat meningkatkan keberlanjutan keseimbangan dalam ikatan aspek sosial dan ekologi (Soto et al., 2008).

Sistem resirkulasi pada akuakultur merupakan teknologi alternatif dalam budidaya ikan dengan menerapkan pendekatan pengelolaan berbasis ekosistem berkelanjutan, dimana sistem resirkulasi pertama kali diterapkan di negara perikanan maju seperti Norwegia. Di sana, sistem resirkulasi mampu menggenjot angka produksi hingga berkali-kali lipat dari sistem lama. Di Indonesia, teknologi dengan sistem modern tersebut pertama kali dikembangkan salah satunya oleh Balai Perikanan Budidaya Air Tawar (BPBAT) Tatelu, Minahasa, Sulawesi Utara (Slamet, 2018). Teknologi sistem resirkulasi pada akuakultur mampu meningkatkan hasil produksi budidaya ikan dengan meminimalisir kerusakan ekosistem sekitar. Beberapa penelitian sudah menunjukkan bagaimana sistem resirkulasi mampu memberikan kontribusi yang signifikan dalam mengurangi potensi degradasi lingkungan.

Sistem resirkulasi ini merupakan metode yang memanfaatkan kembali air yang sudah digunakan dengan cara memutar air secara terus-menerus melalui perantara sebuah filter atau kedalam wadah (Fauzzia et al., 2013). Sistem resirkulasi adalah suatu teknik budidaya air yang unik, pada teknologi atau sistem resirkulasi ikan dapat dipelihara dengan kepadatan yang lebih tinggi. Bahkan volume air yang digunakan tidak berkurang, penambahan air hanya karena terjadi penguapan. Kualitas air pada sistem resirkulasi dijaga dengan proses filtrasi, baik menggunakan filter mekanik atau biologi (biofilter), ozonisasi, dan radiasi dengan sinar ultraviolet (UV) untuk membunuh mikroorganisme pengganggu (Setyono, 2012). Penggunaan sistem resirkulasi dapat menghemat penggunaan air, pengendalian dan pengawasan yang mudah, produksi siginifikan, mampu memanfaatkan lahan yang sempit (Fadhil, 2010)

Budidaya perikanan merupakan salah satu bidang usaha yang ditekuni di wilayah persisir Danau Tondano Kabupaten Minahasa. Salah satunya di Kecamatan Eris, Desa Watumea memiliki pembudidaya ikan yang memanfaatkan sumber daya alam yang ada di pesisir Danau Tondano. Sampai saat ini danau tersebut masih dimanfaatkan oleh pelaku usaha dalam mengembangkan usaha mereka. Usaha budidaya ikan yang dikembangkan adalah KJA yang sejak lama tumbuh subur di pesisir danau. Meningkatnya jumlah KJA berkorelasi dengan meningkatnya degradasi lingkungan. Contoh yang dapat kita lihat di Danau Tondano terjadi eutrofikasi sehingga menyebabkan meningkatnya populasi eceng gondok. Hendriyana (2019) menyatakan bahwa KJA memiliki efek negatif yang dapat membunuh ikan dan merusak ekosistem sekitarnya secara massal akibat penurunan kualitas air.

Permasalahan di atas disebabkan kurangnya pengetahuan pembudidaya terhadap penerapan teknologi alternatif yang ramah lingkungan dalam budidaya ikan. Oleh sebab itu pembudidaya ikan harus mampu memahami akan penerapan teknologi dalam budidaya ikan yang memiliki pendekatan pengelolaan berbasis ekosistem yaitu sistem resirkulasi. Langkah yang dapat diambil pembudidaya ikan adalah dengan meningkatkan pemahaman akan sistem resirkulasi. Meningkatnya pengetahuan atau pemahaman oleh pembudidaya ikan KJA akan penerapan metode budidaya ikan dengan pendekatan pengelolaan berbasis ekosistem, akan sedapat mungkin atau diharapkan dapat mengubah perilaku pembudidaya ikan sehingga lebih peduli terhadap lingkungan sekitar yang berkelanjutan. Tujuan penelitian untuk mengetahui bagaimana persepsi pembudidaya ikan di Desa 
Watumea, Kecamatan eris, Kabupaten Minahasa, Provinsi Sulawesi Utara tentang sistem resirkulasi.

\section{METODE PENELITIAN}

Penelitian ini dilaksanakan di Desa Watumea, Kecamatan Eris, Kabupaten Minahasa, Provinsi Sulawesi Utara pada bulan Maret-Mei 2019. Lokasi penelitian merupakan salah satu sentra dengan KJA. Jenis ikan yang umum atau dominan dibudidayakan adalah ikan mujair (O. mossambicus), ikan nila (Oreochromis niloticus), dan ikan mas (Cyprinus carpio).

Metode yang digunakan dalam penelitian ini adalah kuantitatif-deskriptif (Sugiyono, 2010). Populasi dalam penelitian ini adalah seluruh pembudidaya ikan KJA yang jumlahnya 30 orang. Dari populasi tersebut diambil sampel atau responden sebanyak 21 Orang. Latar belakang pendidikan SMP $19.05 \%$ dan SMA $80.95 \%$ dari total responden. Ratarata responden sudah lebih dari 10 tahun sebagai pembudidaya ikan. Teknik pengambilan sampel adalah Purposive Sampling dengan pertimbangan hanya pada responden yang membudidayakan ikan mujair (O. mossambicus) secara dominan.

Pengumpulan data menggunakan kuesioner yang disebarkan dengan desain berdasarkan skala likert terdiri dari 5 alternatif jawaban yaitu: Sangat Setuju $(\mathrm{SS})=5$, Setuju $(\mathrm{S})=4$, Ragu - Ragu $(\mathrm{RR})=$ 3, Tidak Setuju (TS) $=2$, Sangat Tidak Setuju (STS) $=1$. Sebelum melakukan pengisian keusioner responden mendapatkan penjelasan singkat tentang sistem resirkulasi secara umum oleh staf pengumpul data penelitian. Variabel data penelitian ini fokus pada (1) Persepsi pembudiaya ikan pada recirculating aquacultere system (RAS)/sistem resirkulasi. (2) Persepsi kemauan adopsi recirculating aquacultere system (RAS)/sistem resirkulasi.

Teknik pengolahan data dengan melakukan pengeditan, pengkodean, pemindahan data ke dalam bentuk master tabel, selanjutnya pengelompokkan data dalam bentuk tabel. Nilai distribusi frekuensi jawaban responden (Tabel 1) dalam pengelompokkan data tersebut didapat dengan menggunakan rumus:

$$
\begin{gathered}
\text { Frekuensi relatif }= \\
\frac{f_{i}}{\sum f_{i}} \times 100 \%=\frac{f_{i}}{n} \times 100 \%(\text { Sudjana, 2005) }
\end{gathered}
$$

Keterangan:

$$
\begin{aligned}
f_{\mathfrak{i}}= & \text { banyaknya alternatif jawaban } \\
& \text { yang di pilih } \\
n= & \text { banyaknya total responden }
\end{aligned}
$$

Teknik analisis data nilai distribusi frekuensi persepsi pembudidaya ikan dan nilai distribusi frekuensi persepsi kemauan adopsi dengan analisis univariat menggunakan program Statistical Product and Service Solutions (SPSS) versi 19 (Hidayat \& Istiadah, 2011).

\section{HASIL DAN PEMBAHASAN}

Hasil wawancara atau pengumpulan data diperoleh distribusi frekuensi seluruh jawaban responden seperti diperlihatkan dalam Tabel 1.

Tabel 1 memberikan informasi distribusi frekuensi pernyataan 21 orang responden atas 20 pernyataan. Pernyataan pertama mayoritas menjawab ragu-ragu dan setuju $(47,60 \%)$, pernyataan kedua responden menjawab ragu-ragu $(47,60 \%)$, pernyataan ketiga responden menjawab ragu-ragu dan setuju $(42,90 \%)$, pernyataan keempat mayoritas menjawab ragu-ragu $(47,60 \%)$, pernyataan kelima responden menjawab setuju $(47,60 \%)$, pernyataan keenam mayoritas responden menjawab ragu-ragu dan setuju $(47,60 \%)$, pernyataan ketujuh responden menjawab ragu-ragu $(42,90 \%)$, pernyataan kedelapan responden menjawab ragu-ragu $(47,60 \%)$, pernyataan kesembilan mayoritas responden menjawab raguragu $(42,90 \%)$, pernyataan kesepuluh mayoritas responden menjawab setuju $(61,90 \%)$, pernyataan kesebelas responden menjawab setuju $(71,40 \%)$, pernyataan keduabelas responden menjawab setuju $(61,90 \%)$, pernyataan ketigabelas mayoritas responden menjawab setuju $(81,00 \%)$, pernyataan keempatbelas responden menjawab setuju $(52,40 \%)$, pernyataan kelimabelas responden menjawab setuju $(52,40 \%)$, pernyataan keenambelas responden menjawab setuju $(66,70 \%)$, pernyataan ketujubelas mayoritas responden menjawab setuju $(71,40 \%)$, pernyataan kedelapanbelas mayoritas responden menjawab setuju $(81,00 \%)$, pernyataan kesembilanbelas responden menjawab setuju $(71,40 \%)$, pernyataan keduapuluh responden menjawab setuju $(71,40 \%)$. 
Tabel 1. Distribusi frekuensi jawaban responden per pertanyaan

\begin{tabular}{|c|c|c|c|c|c|c|c|c|c|c|c|}
\hline \multirow{3}{*}{ No } & \multirow{3}{*}{ Pernyataan } & \multicolumn{10}{|c|}{ Kategori penilaian } \\
\hline & & \multicolumn{2}{|c|}{ STS } & \multicolumn{2}{|c|}{ TS } & \multicolumn{2}{|c|}{ RR } & \multicolumn{2}{|c|}{$S$} & \multicolumn{2}{|c|}{ SS } \\
\hline & & $\mathrm{f}$ & $\%$ & $\mathrm{f}$ & $\%$ & $\mathrm{f}$ & $\%$ & $\mathrm{f}$ & $\%$ & $\mathrm{f}$ & $\%$ \\
\hline 1 & $\begin{array}{l}\text { Saya memahami konsep penerapan } \\
\text { RAS pada budidaya ikan }\end{array}$ & - & - & - & - & 10 & 47,60 & 10 & 47,60 & 1 & 4,80 \\
\hline 2 & $\begin{array}{l}\text { Saya memahami penerapan RAS } \\
\text { yang ramah lingkungan }\end{array}$ & - & - & - & - & 10 & 47,60 & 7 & 33,30 & 4 & 19,00 \\
\hline 3 & $\begin{array}{l}\text { Saya memahami RAS merupakan } \\
\text { pengembangan teknologi pada } \\
\text { budidaya ikan }\end{array}$ & - & - & - & - & 9 & 42,90 & 9 & 42,90 & 3 & 14,30 \\
\hline 4 & $\begin{array}{l}\text { Penerapan RAS pada budidaya ikan } \\
\text { memiliki tingkat produksi yang baik }\end{array}$ & - & - & - & - & 10 & 47,60 & 9 & 42,90 & 2 & 9,50 \\
\hline 5 & $\begin{array}{l}\text { Penerapan RAS memiliki kontrol } \\
\text { kualitas kesehatan ikan yang baik }\end{array}$ & - & - & - & - & 9 & 42,90 & 10 & 47,60 & 2 & 9,50 \\
\hline 6 & $\begin{array}{l}\text { Penerapan RAS dapat dilakukan } \\
\text { pada lahan yang tidak luas }\end{array}$ & - & - & 1 & 4,80 & 10 & 47,60 & 10 & 47,60 & - & - \\
\hline 7 & $\begin{array}{l}\text { Penerapan RAS bisa menjadi } \\
\text { alternatif untuk budidaya ikan di } \\
\text { masa depan }\end{array}$ & - & - & - & - & 9 & 42,90 & 7 & 33,30 & 5 & 23,80 \\
\hline 8 & $\begin{array}{l}\text { Penerapan RAS dapat memenuhi } \\
\text { sumber pangan (ikan) }\end{array}$ & - & - & 1 & 4,80 & 10 & 47,60 & 8 & 38,10 & 2 & 9,50 \\
\hline 9 & $\begin{array}{l}\text { Penerapan RAS bisa di dilakukan } \\
\text { oleh siapa saja }\end{array}$ & - & - & - & - & 9 & 42,90 & 8 & 38,10 & 4 & 19,00 \\
\hline 10 & $\begin{array}{l}\text { Pernakah anda berpikir tentang } \\
\text { kualitas air danau yang menurun }\end{array}$ & 1 & 4,80 & - & - & 2 & 9,50 & 13 & 61,90 & 5 & 23,80 \\
\hline 11 & $\begin{array}{l}\text { Pernakah anda mencari metode } \\
\text { budidaya ikan yang ramah } \\
\text { lingkungan }\end{array}$ & 1 & 4,80 & 1 & 4,80 & - & - & 15 & 71,40 & 4 & 19,00 \\
\hline 12 & $\begin{array}{l}\text { Pernakah anda mencari informasi } \\
\text { tentang metode RAS pada budidaya } \\
\text { ikan }\end{array}$ & - & - & 1 & 4,80 & 6 & 28,60 & 13 & 61,90 & 1 & 4,80 \\
\hline 13 & $\begin{array}{l}\text { Pernakah anda berpikir untuk } \\
\text { meningkatkan produksi budidaya } \\
\text { ikan dengan metode yang ramah } \\
\text { lingkungan }\end{array}$ & - & - & - & - & 1 & 4,80 & 17 & 81,00 & 3 & 14,30 \\
\hline 14 & $\begin{array}{l}\text { Pernakah anda berpikir bahwa } \\
\text { metode RAS itu sulit diterapkan }\end{array}$ & 1 & 4,80 & 1 & 4,80 & 7 & 33,30 & 11 & 52,40 & 1 & 4,80 \\
\hline 15 & $\begin{array}{l}\text { Pernakah anda berpikir bahwa biaya } \\
\text { awal penerapan RAS terlalu tinggi }\end{array}$ & 1 & 4,80 & 1 & 4,80 & 7 & 33,30 & 11 & 52,40 & 1 & 4,80 \\
\hline 16 & $\begin{array}{l}\text { Pernakah anda berpikir tentang } \\
\text { pengembangan budidaya ikan } \\
\text { terkini }\end{array}$ & - & - & - & - & 3 & 14,30 & 14 & 66,70 & 4 & 19,00 \\
\hline 17 & $\begin{array}{l}\text { Pernakah anda merasa tertantang } \\
\text { untuk mengembangkan metode } \\
\text { budidaya ikan yang baru }\end{array}$ & - & - & - & - & 1 & 4,80 & 15 & 71,40 & 5 & 23,80 \\
\hline 18 & $\begin{array}{l}\text { Pernakah anda berpikir untuk } \\
\text { melakukan penerapan RAS pada } \\
\text { budidaya ikan }\end{array}$ & - & - & - & - & 3 & 14,30 & 17 & 81,00 & 1 & 4,80 \\
\hline 19 & $\begin{array}{l}\text { Pernakah anda berpikir untuk } \\
\text { mengganti metode lama dengan } \\
\text { metode budidaya ikan yang baru }\end{array}$ & 1 & 4,80 & 1 & 4,80 & - & - & 15 & 71,40 & 4 & 19,00 \\
\hline 20 & $\begin{array}{l}\text { Pernakah anda berpikir bagaimana } \\
\text { berbudidaya ikan yang } \\
\text { memperhatikan kesehatan } \\
\text { lingkungan }\end{array}$ & - & - & - & - & 1 & 4,80 & 15 & 71,40 & 5 & 23,80 \\
\hline
\end{tabular}

Ket: RAS: Recirculating Aquaculture System, STS: Sangat Tidak Setuju, TS: Tidak Setuju,

RR: Ragu - Ragu, S: Setuju, SS: Sangat Setuju. 
Tabel 2. Distribusi frekuensi persepsi pembudidaya ikan tentang sistem resirkulasi

\begin{tabular}{lcc}
\hline Kategori persepsi & frequensi & \% \\
\hline Baik & 12 & 57,10 \\
Kurang Baik & 9 & 42,90 \\
\hline Total & $\mathbf{2 1}$ & $\mathbf{1 0 0}$ \\
\hline
\end{tabular}

Berdasarkan hasil analisis dalam Tabel 2 diketahui bahwa persepsi pembudidaya ikan tentang sistem resirkulasi mayoritas responden memiliki persepsi yang baik $(57,10 \%)$ dan minoritas memiliki persepsi kurang baik $(42,90 \%)$. Hal ini menunjukkan bahwa informasi singkat terkait sistem resirkulasi pada penjelasan awal pengisian angket dapat memberikan gambaran jelas kepada mayoritas responden tentang pemeliharaan sistem resirkulasi, sehingga responden memahami manfaat dan keunggulan sistem resirkulasi pada proses budidaya ikan yang ramah lingkungan. Pengamatan langsung terhadap responden juga dapat memberikan penjelasan bahwa informasi yang repsonden dapat terkait sistem resirkulasi telah menambah wawasan mereka dalam pengelolaan budidaya. Tapi hasil persepsi kurang baik juga memiliki jumlah responden dengan nilai persentasi $42,90 \%$, walaupun masuk dalam kategori responden minoritas namun nilai persentasi $42,90 \%$ cukup menggambarkan bahwa beberapa responden masih memiliki sikap keraguraguan ( Tabel 1) terhadap system resirkulasi, hal ini disebabkan informasi yang mereka dapat terkait metode sistem resirkulasi tersebut masih belum cukup kuat. Oleh sebab itu tetap dibutuhkan kegiatankegiatan atau pemberdayaan masyarakat dalam bidang budidaya ikan melalui penyuluhan, bimbingan teknis, dan praktek langsung.

Tabel 3. Distribusi frekuensi persepsi kemauan adopsi sistem resirkulasi

\begin{tabular}{lcc}
\hline Kategori persepsi & frequensi & $\mathbf{\%}$ \\
\hline Memiliki Kemauan & 9 & 42,90 \\
Tidak Memiliki Kemauan & 12 & 57,10 \\
\hline Total & $\mathbf{2 1}$ & $\mathbf{1 0 0}$ \\
\hline
\end{tabular}

Terdapat beberapa pernyataan yang memiliki nilai frekuensi sebesar 5 atau $23,80 \%$ responden memilih sangat setuju (Tabel 1), respon para responden tersebut dapat memberikan gambaran bahwa seperempat dari toral responden percaya bahwa penerapan sistem resirkulasi bisa menjadi metode alternatif untuk budidaya ikan di masa depan dan responden tersebut memiliki keinginan untuk dapat menerapkan metode budidaya ikan yang memperhatikan kesehatan lingkungan atau lingkungan air yang tidak tercemar, hal ini dapat kita lihat pada pernyataan 7 dan 20 tabel 1 . Artinya para responden tersebut menyadari bahwa dalam menjaga keberlanjutan industri budidaya perikanan untuk masa depan diperlukan suatu metode seperti sistem resirkulasi. Badiola et al., (2012) menyatakan sistem resirkulasi akan memaikan peran penting dalam budidaya perikanan di masa depan dan akan memberikan solusi pengelolaan yang lebih baik. Xiao et al., (2019) dalam penelitiannya bahwa sistem resirkulasi pada budidaya ikan merupakan proses pengolahan yang dapat menjaga kualitas air dan lingkungan serta menjaga produk akuatik berkualitas, aman dan sehat.

Pernyataan 10 tabel 1 memperlihatkan bahwa sebesar 23,80\% responden memilih kriteria sangat setuju, hal ini mengungkapkan bahwa responden tersebut memiliki sikap berpikir kritis bahwa kualitas air danau menurun atau mengalami degradasi lingkungan perairan. Hal ini tentunya disebabkan oleh pengelolaan budidaya perikanan yang konvensional karena banyaknya nutrien sisa pakan ikan yang masuk ke badan air danau. Nutrien berlebih dan tak terkontrol tersebut menyebabkan terjadinya eutrofikasi pada danau (Vinçon-Leite \& Casenave, 2019). Limba fosfat merupakan nutrien penyebab eutrofikasi pada danau. Lebih lanjut (Siahaan et al., 2021) dalam penelitiannya menunjukkan bahwa kelimpahan amoniak dan fosfat pada perairan danau Tondano bersumber dari pakan ikan akuakultur.

Nilai frekuensi tersebut di atas juga terdapat pada pernyataan 17 tabel 1, pada pernyataan tersebut $23,80 \%$ responden memilih kriteria sangat setuju, sehingga memberikan informasi bahwa responden tersebut memiliki keinginan untuk dapat mengembangkan metode baru dalam pengelolaan budidaya ikan yang sedang ditekuni. Kemungkinan yang dapat ditarik bahwa para responden tersebut didorong oleh fakta bahwa perairan sekitar danau telah mengalami pencemaran lingkungan. Indikator rusaknya lingkungan tersebut dapat dibuktikan dengan adanya eutrofikasi sehingga mendorong 
meningkatnya populasi enceng gondok (Nebath, 2008). Meningkatnya populasi enceng gondok merupakan permasalahan yang serius, yang secara tidak langsung para responden terkena dampak dari permasalahan tersebut. Dampak dari meningkatnya eceng gondok salah satunya yaitu sulitnya penetrasi cahaya di dalam air sehingga membuat oksigen terlarut dalam air menurun (Hasyim, 2016). Kurangnya kadar oksigen terlarut dapat menyebabkan kurangnya aktivitas kehidupan pada perairan (Missaghi et al., 2017). Hal ini jelas dapat mengganggu aktivitas budidaya perikanan, Wurtsbaugh et al., (2019) dalam penelitiannya menunjukkan bahwa hal tersebut dapat menyebabkan hipoksia pada perairan sehingga dapat mengganggu produksi ikan dan organisme lainnya.

Berdasarkan hasil analisis dalam Tabel 3 diketahui bahwa mayoritas responden tidak memiliki kemauan adopsi sistem resirkulasi dengan nilai sebesar $57.10 \%$ dan minoritas memiliki kemauan adopsi dengan nilai sebesar 42.90\%. Ini menggambarkan bahwa informasi terkait sistem resirkulasi dapat memberikan gambaran kepada responden tentang manfaat dan keunggulan sistem resirkulasi tersebut. Namun mayoritas responden masih belum berani mengadopsi sistem pemeliharaan tersebut karena masih minim pengetahuan bagaimana proses penerapan sistem resirkulasi tersebut, mulai dari infrastruktur awal sampai proses penerapan dan perawatan dalam penggunaan alat-alat. Khususnya responden masih memiliki sikap keraguan terhadap biaya yang diperlukan dalam penerapan pemeliharaan ikan sistem resirkulasi. Hasil analisis terhadap persepsi kemauan adopsi yang ditampilkan oleh responden tidak bersifat permanen. Karena nilai persentasi responden baik yang tidak memiliki kemauan dan yang memiliki kemauan memiliki rentang nilai yang tidak terlalu jauh. Sehingga ada potensi bagi responden untuk kedepan dalam menerapkan budidaya ikan yang memanfaatkan sistem resirkulasi yang ramah lingkungan.

Pengelolaan budidaya perikanan dengan pendekatan berbasis ekosistem yang ramah lingkungan merupakan hal yang baru bagi responden. Pengelolaan budidaya yang diterapkan oleh responden saat ini masih dalam bentuk budidaya perikanan intensif. Penerapan budidaya ikan secara intensif dalam jangka waktu yang panjang akan memberikan efek samping yaitu degradasi lingkungan. Samsundari dan Wirawan (2013) menyatakan pada budidaya ikan intensif, dengan penebaran ikan yang padat dan dosis pakan tinggi, memiliki efek samping terhadap penurunan kualitas air budidaya yang dipicu oleh tingginya sisa pakan dan sisa metabolisme ikan, yang menghasilkan produk sampingan berupa amonia yang memberikan pengaruh negatif terhadap kualitas air suatu perairan.

Sistem resirkulasi dalam budidaya ikan merupakan pengelolaan budidaya ikan ramah lingkungan, mampu mengontrol penggunaan air, nilai produktivitas yang baik (Setyono, 2012). Pemahaman atau tingkat pengetahuan pembudidaya ikan terhadap manfaat dan kelebihan dari sistem resirkulasi pada budidaya ikan sangat berpengaruh terhadap persepsi responden baik terhadap persepsi pembudidaya ikan tetang sistem resirkulasi maupun terhadap kemauan adopsi sistem resirkulasi.

\section{KESIMPULAN}

Hasil penelitian ini menunjukkan bahwa persepsi pembudidaya ikan tentang sistem resirkulasi mayoritas responden memiliki persepsi yang baik $(57,1 \%)$ dan minoritas memiliki persepsi kurang baik $(42,9 \%)$. Kemudian, persepsi terhadap kemauan adopsi sistem resirkulasi mayoritas responden tidak memiliki kemauan adopsi sistem resirkulasi dengan nilai sebesar $57.1 \%$ dan minoritas memiliki kemauan adopsi dengan nilai sebesar $42.9 \%$.

\section{UCAPAN TERIMA KASIH}

Kami mengucapkan terima kasih kepada Direktorat Riset dan Pengabdian Masyarakat (DRPM) Kementerian Riset, Teknologi, dan Pendidikan Tinggi yang telah memberikan pendanaan dalam penelitian ini dengan skema penelitian dosen pemula (PDP).

\section{DAFTAR PUSTAKA}

Ambari, M. 2017. Seperti apa budidaya perikanan berbasis ekosistem. http://www.mongabay. co.id/2017/05/16/seperti-apa-budidayaperikanan-berbasis-ekosistem/

Ardi, I. 2013. Budidaya ikan sistem keramba jaring apung guna menjaga keberlanjutan lingkungan perairan waduk cirata. Media Akuakultur, 8(1): 23-29. 
Badiola, M., Mendiola, D., \& Bostock, J. 2012. Recirculating aquaculture systems (RAS) analysis: main issues on management and future challenges. Aquacultural Engineering, 51:26-35.

Fadhil, R. 2010. Teknologi sistem akuakultur resirkulasi untuk meningkatkan produksi perikanan darat di Aceh: suatu tinjauan. Aceh Development International Conference, 826833.

Fauzzia, M., Rahmawatu, I., \& Nyoman, W. I. 2013. Penyisihan amoniak dan kekeruhan pada sistem resirkulasi budidaya kepiting dengan teknologi membran biofilter. Jurnal Teknologi Kimia Dan Industri, 2(2):1-7.

Hasyim, N. A. 2016. Potensi fitoremedasi eceng gondok (Eichornia crassipes) dalam mereduksi logam berat seng (Zn) dari perairan danau tempe kabupaten wajo [Universitas Islam Negeri Alauddin Makasar]

Hendriyana, A. 2019. Keramba jaring apung dapat sebabkan kematian ikan massal. Universitas Padjadjaran.

Hidayat, T., \& Istiadah, N. 2011. Panduan lengkap menguasai SPSS 19 untuk mengolah data statistik penelitian (Edisi 1). Mediakita.

Irwan, H. 2018. Potensi kegiatan budidaya perikanan di Pulau Bintan. Researchgate.

Missaghi, S., Hondzo, M., \& Herb, W. 2017. Prediction of lake water temperature, dissolved oxygen, and fish habitat under changing climate. Climatic Change, 141:747-757.

Nebath, J. 2008. Kelimpahan tumbuhan akuatik di danau tondano. Ekoton, 8(2):25-29.

Sampantamit, T., Ho, L., Lachat, C., Sutummawong, N., Sorgeloos, P., \& Goethals, P. 2020. Aquaculture production and its environmental sustainability in Thailand: Challenges and potential solutions. Sustainability (Switzerland), 12(5):1-17.

Samsundari, S., \& Wirawan, G. A. 2013. Analisis penerapan biofilter dalam sistem resirkulasi terhadap mutu kualitas air budidaya ikan sidat (Anguilla Bicolor). Jurnal Gamma, 8(2):8697.
Setyono, D. E. . 2012. Akuakultur dengan sistem resir. Oseanografi, 37(3):45-50.

Siahaan, W. D., Salindeho, I. R. N., \& Tumembouw, S. S. 2021. Dinamika parameter kualitas air di Sentra Akuakultur Danau Tondano pada dekade 2010-an. E-Journal Budidaya Perairan, 9(2):1-11.

Slamet, S. 2018. Teknologi RAS untuk kemajuan perikanan budidaya. http://www.mongabay. co.id/2018/03/15/teknologi-ras-untukkemajuan-perikanan-budidaya-seperti-apa/

Soto, D., Aguilar, M. J., \& Brugere, C. 2008. Building an ecosystem aproach to aquaculture. FAO Publishing.

Sudjana. 2005. Metode statistika (Edisi 6). Tarsito.

Sugiyono. 2010. Metode penelitian kuantitatif, kualitatif dan R dan D. CV Alfabet.

Vinçon-Leite, B., \& Casenave, C. 2019. Modelling eutrophication in lake ecosystems: A review. Science of The Total Environment, 651(2): 2985-3001.

Wurtsbaugh, W. A., Paerl, H. W., \& Dodds, W. K. 2019. Nutrients, eutrophication and harmful algal blooms along the freshwater to marine continuum. WIREs Water, 6(5):1373.

Xiao, R., Wei, Y., An, D., Li, D., Ta, X., Wu, Y., \& Ren, Q. 2019. A review on the research status and development trend of equipment in water treatment processes of recirculating aquaculture systems. Reviews in Aquaculture, 11(3):863-895. 